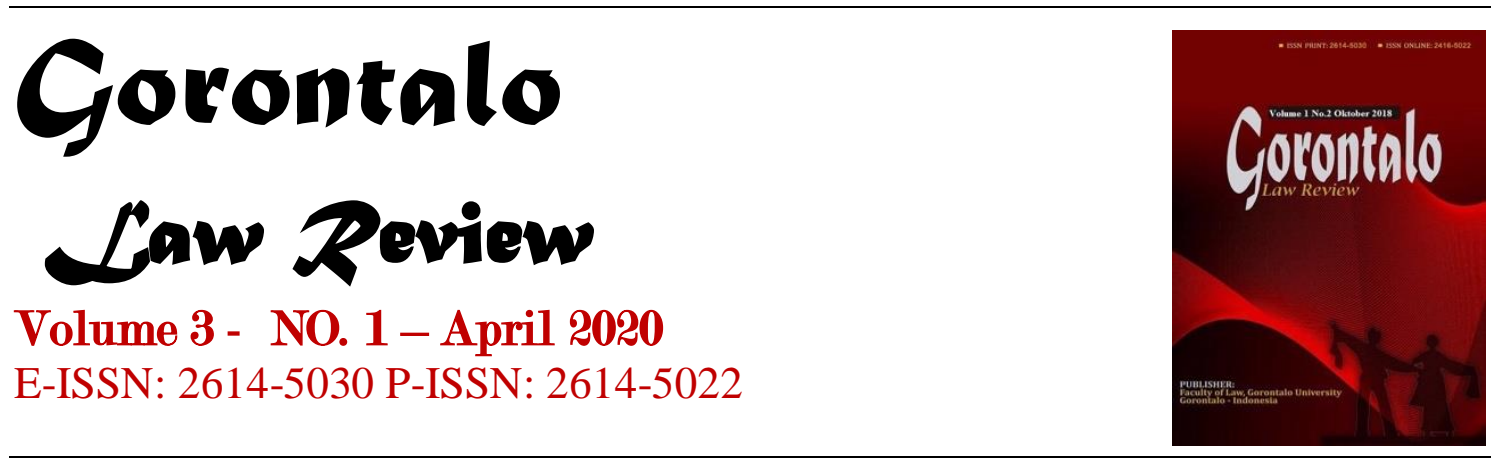

\title{
ANALISIS PERLINDUNGAN HUKUM KONSUMEN PRODUK MAKANAN KEMASAN YANG BEREDAR DI KOTA MAKASSAR
}

\author{
Hj. Sri Lestari Poernomo \\ Fakultas Hukum Universitas Muslim Indonesia \\ srilestaripoernomo68@gmail.com
}

Naskah diterima : 30/3/2020; Direvisi : 16/4/2020; Disetujui: 19/4/2020

\begin{abstract}
Abstrak
Produk makanan kemasan merupakan kebutuhan hidup dan kehidupan manusia, oleh karena itu ketersediaan dan penggunaannya produk tersebut harus terjamin terutama dari aspek perlindungan hukumnya. Dari aspek perlindungan hukumnya, produk yang beredar dalam masyarakat harus memenuhi standar mutu dengan label yang telah terdaftar dari lembaga yang berwenang seperti Badan Pengawasan Obat dan Makanan (BPOM) dengan memperlihatkan komposisi dalam proses produksi dan tata cara penggunaan serta waktu penggunaannya. Selain dari aspek tersebut, juga diperlukan pengawasan yang dapat dilakukan oleh pemerintah, masyarakat melalui Yayasan Lembaga Konsumen Indonesia (YLKI) dan pelaku usaha serta adanya kesadaran hukum masyarakat (konsumen) itu sendiri dalam mengkonsumsi produk makanan kemasan. Adapun tujuan penelitian adalah untuk mengetahui kesadaran hukum pelaku usaha, kesadaran hukum konsumen dan efektivitas pengawasan produk makanan kemasan yang beredar di Kota Makassar. Sedang metode analisisnya adalah deskriptif kuantitatif.Hasil penelitian ini menunjukkan bahwa semua pihak yang terlibat secara sinergitas telah berfungsi dalam melindungi konsumen terutama masyarakat yang mengkonsumsi produk tersebut, meskipun demikian penelitian ini belum secara efektif dapat memuaskan harapan konsumen karena
\end{abstract}


ditemukan masih rendahnya kesadaran hukum pelaku usaha dan kesadaran konsumen itu sendiri.

\title{
Kata Kunci: Kesadaran Hukum Pelaku usaha, konsumen, Efektivitas Pengawasan, Dan Perlindungan Hukum konsumen
}

\begin{abstract}
Packaged food products are a necessities of life and human needs, therefore the avaibility and use of these products should be guaranteed, especially from the aspect of protection. From this aspect, an products have been distributed in the community must meet quality standards with the labels that already registered from authorized institutions such as a government institution in charge of food and drug quality control by showing the composition in production to process and procedure to apply also consumpting time. Moreover, it necessary to have controller by government, community through the foundation of consumer Indonesia and businessman also the existence of community legal awareness (consumer) itself on consuming packaged food products. As a result, this research can concluded that every party whose involved in synergy have been functioned for protecting consumer especially their product community consumer, yet not effectively satisfying consumer community because the number of law awareness around businessman, consumer itself shown a downward trend.
\end{abstract}

\section{Keywords: Law Awareness of Businessman, Consumer, Effectifity of Controling, and Consumer Protection}

\section{PENDAHULUAN}

Dalam praktek bisnis, diperlukan adanya kelangsungan hidup perusahaan (sustainability) dengan berbagai cara untuk memenangkan persaingan usaha, hal inilah yang sering mendorong sebagian pelaku usaha untuk bertindak secara tidak sehat, curang dan bahkan tidak jujur, yang pada akhirnya dapat merugikan kepentingan konsumen. Oleh karena itu, konsumen perlu dilindungi dari kemungkinan timbulnya kerugian sebagai akibat dari perilaku tersebut. Padahal pelaku usaha harus menjaga hubungan baik dengan konsumen terutama dengan adanya kontrak transaksi dengan konsumen yang mengharuskan pihak pelaku usaha bertanggung jawab apabila terjadi wanprestasi dan hal ini sesuai dengan prinsip the privity of contract (Desy Ary Setyawati, Dahlan, M. Nur Rasyid, 2017). Dalam prakteknya seringkali ada ketentuan yang bertujuan melindungi konsumen, terutama konsumen produk makanan dengan cara mencantumkan kode izin edar obat dan makanan luar pada kemasan produk tersebut (Tika Oktaliani, 2016), namun dalam kenyataanya ada saja konsumen yang dirugikan dan mereka tidak mau melaporkannya karena adanya persepsi dan pengalaman bahwa laporan pengaduan yang disampaiakn tidak akan ditindaklanjuti.. 
Di sisi lain dalam penelitian Amanda Putri Sukamto (2013) menemukan bahwa pengetahuan dan pemahaman pelaku usaha tentang Undang-Undang No. 8 Tahun 1999 masih cenderung rendah. Rendahnya pemahaman pelaku usaha tidak hanya dalam hal hukum tertulis/undang-undang, termasuk norma dan etika dalam praktek bisnis. Kepatuhan hukum pelaku usaha produk makanan dalam memenuhi kebutuhan konsumen seperti di Kota Bogor cenderung bersifat heterenomous, karena ditemukan beberapa pelaku usaha yang patuh hukum karena alasan rasa takut (authority oriented), hanya ikut-ikut pelaku usaha lainnya (autonomous), dan didasari oleh kepatuhan sendiri dan tahu aturannya (autonomous). Sedang dalam Pasal 1, ayat (1) dikatakan bahwa segala upaya yang menjamin adanya kepastian hukum untuk memberi perlindungan kepada konsumen.

Selain menuntut kesadaran hukum pelaku usaha, konsumen juga harus memiliki pengetahuan dan pemahaman agar tidak salah dalam memilih dan menggunakan produk makanan. Selain itu, juga diperlukan informasi yang tepat dan benar diterima konsumen terutama terkait dengan gambaran produk diperdagangkan, karena informasi yang bersumber dari pelaku usaha sangat berpengaruh terutama dalam bentuk iklan atau label kehalalan produk, manfaat, bahan baku produk dan masa kadaluarsanya. Informasi yang diberikan oleh pelaku usaha harus sama dengan yang diterima oleh konsumen, oleh karena itu diperlukan adanya kesadaran bersama ke dua belah pihak. Untuk memelihara kesadaran bersama kedua belah pihhak, perlu membangun komitmen bersama dengan mengacu pada standar kontrak dalam perspektif hukum perlindungan konsumen (Sri Lestaari Poernomo, 2018), kemudian memperkuat hasil penelitian (Harianto D, 2016), dan (Hendrawati, 2011).

Beberapa fenomena produk makanan yang terjaring di Makassar pada bulan Ramadhan, banyak jenis makanan jajanan takjil (berbuka puasa), namun perlu diwaspadai dari beberapa jajanan itu mengandung zat kimia yang tak layak dikosumsi. Terkait dengan itu BPOM Makassar pada tanggal 16 agustus 2010 menindaklanjuti kehawatiran masyarakat dengan mengadakan sidak Inspeksi mendadak di pusat jajanan takjil. Kepala Bidang Sertifikasi dan Layanan Informasi Konsumsi BPOM Makassar, dra Adilah Pababari, Apt., MM, bersama stafnya turun langsung dengan mobil laboratorium BPOM untuk meneliti beberapa sampel makanan, dalam sidak ini dicurigai jajanan takjil tersebut mengandung bahan kimia diambil sampelnya lalu di uji, jenis makanan yang diperiksa utamanya jajanan yang warna yang mencolok dan dicurigai mengandung boraks, pewarna Rodhanim B maupun formalin, beberapa diantaranya seperti kerupuk, bolu kukus, es buah dan cendol. Ia menjelaskan mengkosumsi Rhodhamin B dapat berdampak iritasi pada mata, kerusakan hati, tumor dan terakumulasi di dalam tubuh, hal ini karena Rhodhamin B adalah bahan pewarna tekstil, dan dilarang penggunaan pada bahan makanan (Sholehudin Abdul Aziz. 2016)..

Dalam peraturan perundangan Indonesia jelas bahwa setiap kemasan wajib mencantumkan asal bahan tertentu dan kandungannya, misalnya produk makanan yang mengandung babi dalam sidak produk import itu adalah jelly rasa buah dan cola dengan merek dagang harico. Kepada BPOM Kustantinah 
menambahkan, sejauh ini produsen importer yang dicekal usai operasi yang dilakukan BPOM Makassar, mereka kembali memasarkan produk yang dianggap illegal tersebut, meski ada yang sudah diproses secara hukum, paling berat mereka disuruh membayar denda dengan jumlah kurang dari 5 juta rupiah. Kustantinah berharap pemerintah membuat aturan khusus beserta sanksi tegas untuk menindak pengedar dan produsen makanan atau obat illegal, setidaknya memberikan efek jera dan tidak merugikan masyarakat atas produk yang diedarkannya.

Kajian Lembaga Konsumen Jakarta (LKJ) untuk memenuhi amanat Undang-Undang No. 7 Tahun 1996 tentang Pangan yaitu terbebasnya masyarakat dari jenis pangan yang berbahaya bagi kesehatan manusia dan tidak sesuai dengan keyakinan masyarakat, konkretnya yaitu, keamanan pangan dapat dibedakan dalam dua hal besar yaitu aman secara rohani dan aman secara tehnis. Aman secara rohani berubungan dengan kepercayaan agama suatu masyarakat, apalagi untuk sebagian besar konsumen Indonesia yang beragama Islam, maka faktor kehalalan menjadi suatu hal yang sangat mendasar. Terhadap kasus halal haram “ajinomoto" (Januari 2001). Pelaku usaha diduga telah mengganti bahan nutrisi untuk mengembangkan kutur bakteri, dari polypetone menjadi bactosoytone yang mengandung porcine enzim dari pankekreas babi) sejak juni 2000. Perubahan ini tidak pernah diberitahukan kepada Lembaga Pengkajian Pangan, Obat-obatan, dan Kosmetik majelis Ulama Indonesia (LPPOM-MUI), lembaga yang berwenang memberikan sertifikasi halal. Sementara kasus tersebut selesai di tengah jalan (2001), pasal 8 ayat (1) butir h UUPK tentang Perlindungan Konsumen menyisakan ketidakjelasan batasan "halal" di dalamnya, yang memuat rumusan sebagai berikut : "pelaku usaha dilarang memproduksi dan/atau memperdagangkan barang dan/atau jasa yang tidak mengikuti ketentuan berproduksi secara halal, sebagaimana pernyataan halal yang dicantumkan dalam label“.

Hasil riset Novianti (2005), membuahkan kesimpulan "meskipun pemberlakuan ketentuan label halal ditujukan untuk umat Islam, ternyata dapat pula digunakan untuk umat beragama lain". Jadi label halal ini dapat melindungi semua agama yang ada di Indonesia. Sedangkan ciri tehnis keamanan pangan yang diungkap dalam draff Konsumen Jakarta (LKJ), yaitu tidak mengandung cemaran yang berbahaya, baik secara kimia, fisik, maupun mikrobiologi. Kritik tim LKJ terhadap data rangkuman kasus keracunan pangan tahun 2001 - 2005 yang dikeluarkan Badan Pengawas Obat dan Makanan (sumber: BPOM ,2005) mengatakan data tersebut masih sangat kasar dan belum cukup atau kurang lengkap untuk menjadi dasar di dalam mengambil kebijakan atau keputusan.

Berdasarkan Undang-Undang No. 7 Tahun 1999 tentang pangan dan sesuai Peraturan Pemerintah No. 28 Tahun 2004 tentang Keamanan, Mutu dan Gizi Pangan, peredaran obat dan makanan diatur bahwa setiap pangan yang akan masuk dan beredar di Indonesia harus memenuhi keamanan, mutu dan gizi pangan yang dibuktikan dengan kelengkapan hasil uji dan pemeriksaan dari negara asal (Iqlimatul Annisa, 2018). Selanjutnya, apabila dalam penerapan Undang-Undang tersebut mmaka pemerintah akan menerapkan sanksii 
administratif, sanksi pidana pokok, sanksi pidana tambahan jika dianggap prooduk yang dipasarkan oleh pelaku usaha akan membahayakan konsumen (Hamsyar, 2017).

Berdasarkan latar belakang masalah tersebut, maka permasalahan yang hendak dirumuskan dalam penelitihan ini adalah (1) Sejauhmana kesadaran hukum pelaku usaha dapat melindungi konsumen dalam mengkonsumsi makanan yang beredar di Kota Makassarr, (2) Sejaumana kesadaran hukum masyarakat dalam memilih dan menggunakan produk makanan. dan (3) sejauhmana efektifitas pengawasan dilakukan pemerinttah dalam perlindungan hukum kepada konsumen makan yang beredar di Kota Makassar.

Adapun tujuan penelitian yang hendak dicapai adalah (1) untuk mengetahu sejauhmana kesadaran hukum pelaku dapat melindungi konsumen yang mengkonsumsi makanan beredar di Kota Makassar, (2) untuk mengetahui tingkat kesadaran masyarakat dalam memilih dan menggunakan makanan yang beredar di Kota Makassar, dan (3) untuk mengetahui efektivitas pengawasan terhadap peredaran obat dan makanan dalam melindungi konsumen makanan beredar di Kota Makassar.

Penelitian ini diharapkan dapat memberi manfaat (1) bagi pelaku usaha agar dapat menyadari betapa besar tanggung jawab yang harus dipikul dalam memberikan perlindungan hukum bagi konsumen yang memilih dan menggunnakan produk makanan yang diperjjual belikannya, (2) bagi konsumen akan mengetahui bahwa selain tanggung jawab hukum pelaku usaha dan pemerintah juga dituntut tingkat kesadaran yang tinggi bagi konsumen itu sendri dalam memilih dan mengkonsumsi produk makanan, dan (3) bagi pihak berkepentingan terutama dalam melakukan pengawasan produk makanan yang beredar dalam masyarakat.

Untuk memecahkan permasalahan yang dihadapi oleh pelaku usaha, konsumen dan lembaga yang diberi amanah untuk melakukan pengawasan dalam perlindungan konsumen terutama produk makanan diperlukan suatu rujukan berupa teori dan konsep-konsep yang dapat menjadi pegangan kuat untuk menggali pengetahuan dan pemahanan terhadap pentingnya perlindungan hukum bagi konsumen. Menurut Gunawan Widjaja (2001) kewajiban pelaku usaha merupakan konsekwensi dari adanya hak konsumen. Kewajiban tersebut dimaksudkan untuk menciptakan "budaya" bertanggung jawab dalam diri pelaku usaha. Kewajiban beritikat baik dalam melakukan kegiatan berusaha merupakan salah satu asas yang dikenal dalam hukum perjanjian. Dalam UUPK tampaknya itikat baik lebih di tekankan bagi pelaku usaha, karena meliputi semua tahapan awal dalam melakukan kegiatan usahanya, sehingga dapat diartikan bahwa kewajiban pelaku usaha untuk beritikat baik dimulai sejak barang dirancang/diproduksi sampai pada tahap purna jual (Erleni, 2016). Hal ini tentu saja dimaksudkan karena kemungkinan terjadinya kerugian bagi konsumen dimulai sejak barang diproduksi oleh produsen. Sedang bagi konsumen, kemungkinan untuk merugikan produsen mulai pada saat melakukan transaksi dengan produsen/pelaku usaha.

Di samping adanya hak, kewajiban yang perlu diperhatikan pelaku usaha, ada juga tanggung jawab yang harus dipikulnya. Tanggung jawab tersebut 
merupakan bagian dari kewajiban yang mengikat mereka dalam berusaha. Tanggung jawab ini juga disebut dengan istilah product liability (tanggung gugat produk). Sebagaimana dibahas sebelumnya, pada perkembangan pada masa kini produsen memiliki kewajiban untuk selalu berhati-hati dalam memproduksi barang atau jasa yang dihasilkannya. Logikanya berdasarkan hukum segala bentuk pelanggaran yang dilakukan oleh pelaku usaha meminta pertanggungjawaban dari pelaku usaha yang telah merugikannya (Happy Susanto: 2008).

Product liability adalah suatu tanggung jawab secara hukum dari orang/badan yang menghasilkan suatu produk (producer atau manufacturer), dari orang/badan yang bergerak dalam suatu proses untuk menghasilkan suatu produk (processor and assembler) atau mendistribusikan (seller and distributor) produk tersebut (Saefullah, 2000). Ada pula definisi lain tentang product liability yaitu "suatu konsepsi hukum yang dimaksudkan untuk memberikan perlindungan kepada konsumen, yaitu dengan jalan membebaskan konsumen dari beban untuk membuktikan kerugian konsumen timbul akibat kesalahan dalam proses produksi dan sekaligus melahirkan tanggung jawab produsen untuk memberikan ganti rugi " (Siahaan dalam Sri Lestari, 2018)

Menurut UU Perlindungan Konsumen Pasal 1 angka 2 bahwa "Konsumen adalah setiap orang pemakai barang dan/atau jasa yang tersedia dalam masyarakat, baik bagi kepentingan diri sendiri, keluarga, orang lainmaupun mahkluk hidup lain dan tidak untuk diperdagangkan" Dalam hubungan atau transaksi ekonomi yang merupakan salah satu bentuk pola pemenuhan kebutuhan manusia yang saling interdependen, terjadi posisi saling berhadapan yaitu antara konsumen dan produsen/pelaku usaha. Kedua posisi ini penting dicermati agar terjadi hubungan yang "Seimbang", dalam ilmu konsumen sebagaimana dikemukakan oleh Siahaan (2005) ada 2 (dua ) teori tentang posisi konsumen dan produsen, yaitu (1) teori memandang perlunya keseimbangan (balances) yang berawal dari "let the buyer beware" yakni pembeli harus bersikap hati. Kemudian teori ini berkembang bahwa produsen juga harus memiliki kewajiban selalu bersikap hati-hati dalam memproduksi barang dan/jasa. Teori ini jauh lebih baik di bandingkan dengan yang pertama, di mana produsen diwajibkan selalu berhati-hati karena mereka lebih mengetahui kondisi produknya sendiri, baik sejak proses produksi hingga pemasarannya ke konsumen. Konsekwensi dari sikap ini adalah produsen harus menanggung "kesalahan" (liability), jika ternyata ada produknya yang merugikan konsumen.Sebaliknya, produsen tidak bisa dipersalahkan atau dimintai pertanggungjawaban jika ternyata mereka telah berhati- hati. Dari sini kemudian berkembang konsep "ganti rugi", jika melakukan kesalahan dan daat merugikan konsumen atau masyarakat, produsen harus memberikan ganti rugi sebagaimana seharusnya menurut Undang-Undang Perlindungan konsumen.

Kuatnya posisi pelaku usaha karena konsumen berada pada posisi hanya menerima dan menikmati produk yang dihasilkan oleh pelaku usaha/produsen. Pada umumnya konsumen adalah masyarakat yang memiliki kondisi ekonomi lemah dan tidak mempunyai banyak pilihan kecuali menikmati produk yang 
dihasilkan oleh pelaku usaha. Sementara pelaku usaha lebih mengetahui persis kondisi, keadaan dan kualitas produk yang dihasilkanya.

Jika demikian halnya, maka konsumen senantiasa lebih berhati-hati dalam memilih dan menggunakan produk yang beredar dalam masyarakat/pasar. Konsumen harus memiliki pengetahuan dan pemahaman tentang produk tersebut, barulah mengambil sikap apakah produk tersebut memenuhi syarat/layak untuk dikonsumsi atau sebaliknya. Dengan demikian posisi lemah yang disandang oleh konsumen dalam hal mengajukan ganti kerugian tidak akan terjadi, karena konsumen dalam memilih dan menggunakan produk dapat terseleksi dengan baik.

Meskipun sifat kehati-hatian berada pada pelaku usaha dan konsumen, akan tetapi pengawasan juga sangat diperllukan dalam melindungi kepentingan keduanya, sebagaimana dalam satu fungsi dasar manajemen yang sering disebut dengan controlling oleh Sujamto (1989) fungsi kontrolling itu ada dua padanan yaitu pengawasan dan pengendalian. Selanjutnya dikatakan pula bahwa pengawasan adalah segala usaha atau kegiatan untuk mengetahui dan menilai kenyataan yang sebenarnya tentang pelaksanaan tugas atau kegiatan sesuai dengan semestinya. Sedang Siagian (2001) pengawasan adalah keseluruhan upaya pengamatan pelaksanaan kegiatan operasional guna menjamin bahwa kegiatan tersebuat sudah sesuai dengan rencana yang telah ditetapkan sebelumnya. George G. Terry, mengatakan pengawasan adalah untuk menentukan apa yang telah dicapai, mengadakan evaluasi atasnya dan mengambil tindakan korektif, bila diperlukan untuk menjamin agar hasilnya sesuai dengan rencana (Kosasibi Taruna Soepaji dalam Meliza Edtriani, 2012). Hasil penelitian Meliza EdTriani (2012) menyimpulkan bahwa pelaksanaan pengawasan makanan dan minuman tanpa izin edar (TIE) di Kota Pekanbaru dinilai dengan kategori masih "Cukup baik" hal ini dapat dibuktikan dengan masih terdapatnya makanan dan minuman tanpa izin edar yang beredar di pasaran.

Pengawasan terhadap penyelenggaraan perlindungan konsumen serta penerapan peraturan perundang-undangan diselenggarakan oleh Pemerintah dan Masyarakat. Pengawasan yang dilakukan oleh masyarakat terhadap produk misalnya pangan yang beredar di tengah masyarakat. hasil dari pemantaun dapat dipublikasikan kepada masyarakat dan kepada menteri/menteri terkait. Apabila ternyata, produk yang beredar di masyarakat menyimpang dari peraturan perundang- undangan yang berlaku dan dapat membahayakan konsumen, menteri dan atau menteri terkait, dapat mengambil tindakan. Sedang pengawasan yang dilakukan oleh masyarakat dapat melalui (1) Majelis Ulama Indonesia mengenai sertifikasi label halal dan (2) Organisasi independent yang menerbitkan Indonesian costumer Satisfaction Award.

Undang-Undanga Perlindungan Konsumen (UUPK) yang secara khusus mengatur mengenai perlindungan konsumen, pelaku usaha, penyelesaian sengketa, dan pengagawasan konsumen dan Undang- Undang Pangan yang mengatur khusus mengenai perlindungan produk pangan agar dapat memenuhi nilai-nilai dasar tersebut di atas, perlu memperhatikan nilai filosofis, sosiologis dan yuridis dalam pembentukannya. Satjipto Rahardjo (1986: 68) 
mengemukakan bahwa: (a) Filosofi adalah padangan hidup bangsa Indonesia dalam berbangsa dan bernegara, yaitu Pancasila. Penjabaran nilai-nilai Pancasila dalam hukum mencerminkan suatu keadilan, ketertiban dan kesejateraan yang diinginkan oleh masyarakat Indonesia, (b) Sosiologi, yaitu budaya bangsa Indonesia yang tumbuh dan berkembang sesuai dengan kesadaran masyarakat Indonesia yang berbhineka Tunggal Ika, berwawasan Nusantara, dan (c) Yuridis, yaitu nilai-nilai dasar UUD 1945, yang dijiwai oleh nilai-nilai keadilan bagi seluruh lapisan masyarakat yang tidak memihak kepada kepentingan orang seorang saja, melainkan kepentingan orang banyak.

Alasan diperlukannya perlindungan hukum bagi konsumen adalah bervariasinya barang dan jasa yang beredar, baik hasil produksi dalam negeri maupun hasil produksi luar negeri, karena perkembangan di bidang perdagangan dan perindustrian nasional, serta adanya arus globalisasi. Kondisi demikian dapat mengakibatkan kedudukan pelaku usaha dan konsumen menjadi tidak seimbang. Dalam hal ini, konsumen berada pada posisi yang lemah, sehingga diperlukan perlindungan hukum bagi konsumen tetapi tetap memperhatikan kepentingan pelaku usaha. Keseimbangan itu hanya dapat dicapai dengan campur tangan negara melalui sistem HPK yang diharapkan dapat memberdayakan konsumen, karena tidak mudah mengharapkan kesadaran pelaku usaha yang berpegang pada prinsip ekonominya (Pertimbangan pembentukan UUPK dan penjelasan Umum UUPK)

Selanjutanya masih dalam konsep teori yang terkait dengan Perlindungan hukum konsumen pangan yaitu "konsep tentang Pelayanan Publik" bahwa menurut Pasal 1 ayat (1 ) UU No. 37 Tahun 2008 menyebutkan bahwa Ombudsman adalah lembaga negara yang mempunyai kewenangan mengawasai penyelenggaraan pelayanan publik" baik yang diselenggarakan oleh peyelenggara negara atau pemerintah, termasuk yang di selenggarakan oleh BUMN, BUMN, dan BHMN, serta badan swasta atau perorangan yang diberi tugas menyelenggarakan pekerjaan publik tertentu dan sebagian atau seluruh dananya bersumber dari APBN dan/atau APBD. Undang - Undang ini terkait langsung dengan Undang - Undang No. 28 Tahun 1999 tentang Penyelenggaraan Negara menetapakan asas - asas Umum Penyelenggaraan negara yang terkait dengan “ Pelayanan Publik " yaitu : Asas kepastian hukum, Asas tertib penyelengaraan negara, Asas kepentingan umum, asas keterbukaan, Asas proposionalitas, Asas profesionalisme dan asas akuntabilitas. (Mukarom \& Muhimudin; 2015)

Asas hukum (rechtsbeginsel) adalah dasar dari peraturan-peraturan, yang mengkualifikasikan (kwalificeren) beberapa peraturan hukum. Sehingga peraturan-peraturan hukum itu bersama-sama merupakan satu lembaga hukum (Satjipto Rahardjo, 2008). Asas hukum merupakan pondasi suatu perundang-undangan. Bila asas hukum tersebut dikesampingkan, maka bangunan undang-undang dan segenap peraturan pelaksanaannya akan runtuh, Satjipto Rahardjo (2008), mengatakan asas hukum, bukan peraturan hukum pokok pikiran yang bersifat umum dan menjadi latar belakang dari peraturan hukum yang konkret (hukum positif). Selanjutnya beliau juga mengatakan bahwa asas hukum adalah jiwanya peraturan hukum karena ia merupakan dasar lahirnya peraturan hukum, ia adalah rasio legisnya peraturan hukum. 
Asas-asas Hukum Perlindungan konsumen yang dikelompokkan dalam 3 (tiga) kelompok yaitu asas keadilan, kemanfaatan dan kepastian hukum. Dalam hukum ekonomi keadilan disejajarkan dengan asas keseimbangan, kemanfaatan disejajarkan dengan asas efisiensi. Asas kepastian hukum disejajarkan dengan asas efisiensi karena menurut Himawan bahwa Hukum yang berwibawa berarti hukum yang efisiensi, di bawah naungan mana seseorang dapat melaksanakan hak-haknya tanpa ketakutan dan melaksanakan kewajibannya tanpa penyimpangan.

Sedang dalam teori tujuan hukum yang bisa dikategorikan agak lengkap dan komplek adalah apa yang dikemukakan oleh Roscou Pound mengemukakan bahwa tujuan hukum untuk melindungi kepentingan manusia (law as tool of social engineering) (Roscou Pound, dalam Lili Rasyidi, 2002) kepentingan manusia adalah suatu tuntuntan yang dilindungi dan dipenuhi manusia dalam bidang hukum. Roscou Pound membagi kepentingan manusia yang dilindungi hukum menjadi 3 (tiga), yaitu: public interest (kepentingan umum), social interest (kepentingan masyarakat) dan privat interest (kepentingan individu) (Lili Rasyidi, 1988:228 - 231). Kepentingan umum yang utama meliputi (a). Kepentingan negara sebagai badan hukum dalam mempertahankan kepribadian dan substansinya; dan (b) Kepentingan-kepentingan dari negara sebaga penjaga kepentingan masyarakat.

Terkait dengan tujuan perlindungan Konsumen yang sejalan dengan tujuan hukum umum, tujuan di bentuknya Undang-Undang Pangan juga sejalan dengan ke-2 tujuan tersebut, dijelaskan sebagai berikut, "Tujuan Peraturan, Pembinaan, dan Pengawasan Pangan adalah: (a) tersedianya pangan yang memenuhi persyaratan keamanan, mutu, dan gizi bagi kepentingan kesehatan manusia, (b) terciptanya perdagangan pangan yang jujur dan bertanggung jawab dan, (c) tercukupnya tingkat kecukupan pangan dengan harga yang wajar dan terjangkau sesuai dengan kebutuhan masyarakat (sumber, Penjelasan Undangundang Pangan).

Sebagaimana konsep teori kemanfaatan yang terkait dalam fokus penelitian ini, untuk tataran "Aplication Theory" Keseimbangan atau Harmoni dari tujuan hukum Timur yang menjadi rujukan dalam penelitian ini yaitu tujuan hukum adalah keadilan dan keadilan adalah harmonisasi (keseimbangan), harmonisasi (keseimbangan) adalah kedamaian. Jadi berbeda dengan tujuan hukum Barat, maka tujuan hukum bangsa- bangsa Timur yang masih menggunakan kultur hukum asli mereka, salah satu contohnya adalah Jepang, sama sekali tidak menggunakan konsep tujuan hukum barat, yaitu keadilan, kemanfaatan dan kepastian hukum. di Jepang di mana para penegak hukum lebih berorentasi pada tujuan hukum yaitu harmonisasi (keseimbangan) menuju perdamaian (peace) dalam istilah Jepangnya Heiwa atau Heion, tetapi sebenarnya dalam paradikma hukum di Jepang tujuan hukum hanyalah Chiad Hanji (justice of the peace) yaitu keadilan dari harmonisasi (keseimbangan) dan perdamaian. Hukum di Jepang menciptakan perdamaian bagi warga masyarakat, dan di dalam perdamaian itu terkandung keadilan.

Pengertian konsumen dalam arti umum adalah pemakai, pengguna dan/atau pemanfaat barang dan/atau jasa untuk tujuan tertentu. (Sumarwan 
2011 dalam Sri Lestari, 2018). Berdasarkan pengertian tersebut di atas adalah subyek yang disebut sebagai konsumen berarti orang yang berstatus sebagai pemakai barang dan jasa. Istilah "orang" sebetulnya menimbulkan keraguan, apakah hanya orang individual yang lazim disebut natuurlijke person atau termasuk juga badan hukum atau recht person. Menurut Nasution, orang yang dimaksudkan adalah orang alami bukan badan hukum. Sebab yang memakai, menggunakan dan yang memanfaatkan barang atau jasa untuk kepentingan sendiri, keluarga, orang lain, maupun mahkluk hidup lain tidak untuk diperdagangkan hanyalah orang alami atau manusia.

Dalam pasal 6 UUPK diatur bahwa "Kewajiban konsumen adalah (a) membaca atau mengikuti petunjuk informasi dan prosedur pemakaian atau pemanfaatan barang dan/atau jasa demi keamanan dan keselamatan; (b) beritikat baik dalam melakukan transaksi pembelian barang dan/atau jasa; (c) membayar sesuai dengan nilai tukar yang disepakati; dan (d) mengikuti upaya penyelesaian hukum sengketa perlindungan konsumen secara patut". Selain mempunyai hak, konsumen juga dibebani kewajiban. Adapun analisis terhadap ketentuan tersebut, penulis menggunakan uraian-uraian yang dikemukakan oleh Ahmadi Miru dan Sutarman Yodo (2004), bahwa konsumen wajib: (a) membaca atau mengikuti petunjuk informasi dan prosedur pemakaian atau pemanfaatan barang dan/atau jasa demi keamanan dan keselamatan merupakan hal yang penting, mengingat seringnya pelaku usaha menyampaikan peringatan dan instruksi secara jelas pada label suatu produk, namun konsumen tidak membacanya. (b) beritikat baik hanya tertuju pada saat transaksi pembelian barang dan/atau jasa. Dan (c) mengikuti upaya penyelesaian 49 okum sengketa perlindungan konsumen secara patut adalah untuk mengimbangi hak konsumen untuk mendapatkan upaya penyelesaian hukkum sengketa perlindungan konsumen secara patut.

\section{METODE PENELITIAN}

Dalam melakukan suuatu penellitian ilmiah jelas harus menggunakan metode, karena ciri khas penemuan ilmu adalah menggunakan metode. Metode artinya melakukan penyelidikan berlangsung untuk mencapai tujuan. Olehnya itu, penelitian ini menggunakan metode ilmiah dengan membatasi secara tegas bahasan yang dipakai adalah bahasa hukum yang dipahami oleh setiap pengembang ilmu hukum (H.J. Van Eikema Hoommes dalam Jonaedi Efendi dan Johnny Ibrahim, 2018). Jenis penelitian ini adalah penelitian empiris, penelitian dengan data-data lapangan sebagai sumber data utama dengan menggunakan kuesioner. Penelitian empiris digunakan untuk menganalisis hukum yang dapat dilihat sebagai perilaku masyarakat yang berpola dalam kehidupan masyarakat yang selalu berinteraksi dan berhubungan dalam aspek kemasyarakatan (Bambang Sunggono, 2003). Pendekatan penelitian ini menggunakan mendekatan deduktif - induktif yaitu suatu cara analisis konsep dan lapangan yang dapat menghasilkan data yang dinyatakan secara tertulis atau lisan serta juga tingkah laku yang nyata (Mukti Fajar dan Yulianto Achmad, 2010). 


\section{PEMBAHASAN}

Data yang dijadikan dasar deskripsi penelitian adalah tanggapan responden terhadap masing-masing indikator yang membentuk variabel dengan menggunakan skor angka-angka dengan tiga skala masing-masing 1 adalah rendah/kurang baik, 2 adalah cukup tinggi/baik, dan 3 adalah tinggi/baik. Adapun variabel yang diteliti adalah: (a) Efektivitas Pengawasan, (b) Kesadaran Pelaku Usaha), (c) (Kesadaran Hukum Konsumen, dan (d)) Perlindungan Hukum Konsumen.. Untuk mengetahui deskripsi tanggapan responden untuk masing-masing indikator pada masing-masing variabel, dapat di uraikan sebagai berikut:

\section{a. Deskripsi Kesadaran Hukum Pelaku Usaha}

Menurut Pasal 1 angka 3 Undang-Undang Nomor 8 Tahun 1999 tentang Perlindungan Hukum Konsumen bahwa setiap orang perorangan atau Badan Usaha, baik yang berbentuk badan hukum maupun badang hukum yang didirikan dari berkedudukan atau melakukan kegiatan dalam wilayah hukum negara Republik Indonesia baik sendiri maupun bersama-sama melalui perjanjian menyelenggarakan kegiatan usaha dalam berbagai bidang ekonomi. Sedang jika dilihat dari tingkat kesadaran hukumnya bahwa kesadaran diri sendiri dilakukan tanpa tekanan, paksaan atau perintah dari luar untuk tunduk hukum yang berlaku. Variabel kesadaran hukum pelaku usaha dibentuk oleh adanya peraturan pemerintah yang harus ditaati, standar mutu produk yang harus dipedomani, harus memiliki sertifikat mutu, mengetahui dan memahami adanya sanksi hukum jika melanggar, mematuhi aturan dan etika dalam memasang iklan, melaksanakan kewajiban ganti kerugian apabila konsumen dirugikan, dan mencari keuntungan (profit) sesuai kewajaran. Untuk mengetahui tanggapan responden terhadap kesadaran hukum pelaku usaha , maka berikut ini akan ditunjukkan dalam tabel 1 .

Tabel 1. Deskripsi Tanggapan Responden Terhadap Kesadaran Hukum Pelaku Usaha

\begin{tabular}{llccccccc}
\hline \multirow{2}{*}{$\mathbf{N}$} & \multirow{2}{*}{ Indikator } & \multicolumn{2}{c}{$\mathbf{1}$} & \multicolumn{2}{c}{$\mathbf{2}$} & $\mathbf{3}$ & \multirow{2}{*}{ Rata2 } \\
\cline { 3 - 9 } $\mathbf{0}$ & & $\mathbf{F}$ & $\mathbf{\%}$ & $\mathbf{F}$ & $\mathbf{\%}$ & $\mathbf{F}$ & $\mathbf{\%}$ & \\
\hline 1 & Peraturan Pemerintah & 5 & 8,33 & 20 & 33,33 & 35 & 58,33 & 2,50 \\
\hline 2 & Standar Mutu Produk & 7 & 11,67 & 19 & 31,67 & 34 & 56,67 & 2,45 \\
\hline 3 & Sertifikat Mutu & 6 & 10,00 & 19 & 31,67 & 35 & 58,33 & 2,48 \\
\hline 4 & Sanksi Hukum & 3 & 5,00 & 20 & 33,33 & 37 & 61,67 & 2,57 \\
\hline 5 & Iklan Produk & 8 & 13,33 & 19 & 31,67 & 33 & 55,00 & 2,51 \\
\hline 6 & Ganti Kerugian & 4 & 6,67 & 21 & 35,00 & 35 & 58,33 & 2,52 \\
\hline 7 & Profit & 9 & 15,00 & 22 & 36,67 & 29 & 48,33 & 2,33 \\
\hline & & \multicolumn{7}{c}{ Mean } \\
\hline
\end{tabular}

Sumber: Hasil Olahan Data, 2019

Tabel 1 di atas, menunjukkan tanggapan respondem terhadap ketujuh indikator kesadaran hukum pelaku usaha memiliki nilai yang cukup bagus karena berada pada kisaran nilai rata-rata 2,48. Artinya tingkat kesadaran hukum para pelaku usaha makan kemasan yang beredar di Kota Makassar dapat memberikan keyakinan dan kepercayaan bagi konsumen agar tidak kuatir atau ragu mengajukan tuntutan kepada pelaku usaha jika ada konsumen yang 
dirugikan karena membeli dan mengkonsumsi produknya. Selain itu, para pelaku usaha senantiasa taat pada peraturan pemerintah, menerapkan standar mutu sesuai BPOM, produknya memiliki sertifikat mutu, takut dikenai sanksi hukum jika melakukan pelanggaran, iklan yang disampaikan sesuai dengan keberadaan produknya, menjamin akan diberikan ganti kerugian jika terbukti terdapat konsumen yang dirugikan, dan pelaku usaha tidak hanya mementingkan atau memburu keuntungan (profit) tetapi juga tanggung jawab sosial perusahaan (social corporate responsibility). Meskipun demikian, jika diamati secara keseluruhan deskripsi tanggapan dari hasil penelitian ini masih terdapat beberapa pelaku usaha yang memiliki kategori nilai angka 1, artinya masih ada beberapa pelaku usaha yang belum memiliki kesadarah hukum sesuai yang diharapkan..

\section{b. Deskripsi Kesadaran Hukum Konsumen}

Konsumen adalah setiap orang pemakai barang dan/atau jasa yang tersedia dalam masyarakat, baik bagi kepentingan diri sendiri, keluarga, orang lain, maupun makhluk hidup lain, dan tidak untuk diperdagangkan. Jika tujuan pembelian produk tersebut untuk dijual kembali, maka dia disebut pengecer atau distributor. Adapun indikator yang membentuk variabel kesadaran hukum konsumen adalah pengetahuan, pemahaman, sikap dan perilaku konsumen yang mengkonsumsi makanan kemasan yang beredar di Kota Makassar. Kesadaran hukum konsumen dalam mengkonsumsi produk tersebut dapat diketahui melalui tanggapan responden yang dapat diuraikan dalam tabel 2 berikut ini:

Tabel 2. Deskripsi Tanggapan Responden Terhadap Kesadaran Hukum Konsumen

\begin{tabular}{llccccccc}
\hline \multirow{2}{*}{$\mathbf{N}$} & \multirow{2}{*}{ Indikator } & \multicolumn{3}{c}{$\mathbf{1}$} & $\mathbf{2}$ & & $\mathbf{3}$ & Rata \\
\cline { 3 - 9 } $\mathbf{0}$ & & $\mathbf{F}$ & $\mathbf{\%}$ & $\mathbf{F}$ & $\mathbf{\%}$ & $\mathbf{F}$ & $\mathbf{\%}$ & $\mathbf{2}$ \\
\hline 1 & Pengetahuan & 4 & 6,67 & 25 & 41,67 & 31 & 51,67 & 2,45 \\
\hline 2 & Pemahaman & 5 & 8,33 & 23 & 38,34 & 32 & 53,33 & 2,45 \\
\hline 3 & Sikap & 6 & 10,00 & 20 & 33,33 & 34 & 56,67 & 2,47 \\
\hline 4 & Perilaku & 5 & 8,33 & 21 & 35,00 & 34 & 56,67 & 2,48 \\
\hline \multicolumn{7}{c}{ Mean } \\
\hline
\end{tabular}

Sumber: Hasil Olahan Data, 2019

Tabel 2 di atas menunjukkan bahwa tanggapan responden terhadap keempat indikator kesadaran hukum konsumen yang mengkonsumsi produk makanan kemasan yang beredar di Kota Makassar memiliki nilai angka rata-rata 2,46. Artinya tingkat kesadaran hukum konsumen memiliki kategori cukup bagus yang ditunjukkan melalui pengetahuan, pemahaman, sikap dan perilaku konsumen. Tingginya tingkat kesadaran hukum konsumen tersebut karena konsumen mampu menilai dan mengetahui produk yang harus dikonsumsi, kemudian mampu memahami manfaat dan kegunaan produk tersebut, memiliki sikap bahwa produk yang akan dibeli sesuai dengan kemampuan dan kebutuhannya, dan konsumen memiliki perilaku yang baik mulai melakukan pencarian, pemilihan, pembelian, dan mengkonsumsi serta melakukan evaluasi terhadap produk yang dikonsumsinya. Meskipun demikian, jika diamati tanggapan responden masih terlihat adanya tanggapan yang memiliki kategori 
nilai angka 1, artinya dari 60 orang konsumen makanan kemasan masi terdapat beberapa memiliki tingkat kesadaran yang rendah di dalam mengkonsumsi produk kemasan yang beredar di Kota Makassar.

\section{c. Deskripsi Efektivitas Pengawasan}

Pengawasan adalah suatu aktivitas yang dilakukan oleh pihak-pihak yang berkepentingan untuk menjamin bahwa kegiatan-kegiatan dapat memberikan hasil sesuai dengan yang diharapkan. Adapun pihak yang dinilai dalam melakukan pengawasan adalah Dinas kesehatan, Dinas Perdagangan dan Industri, Badan Pengawas Obat dan Makanan (BPOM), Yayasan Lembaga Konsumen Indonesia (YLKI), dan Pelaku Usaha itu sendiri. Sedang yang menilai efektivitas pengawasan obat dan makanan adalah konsumen atau masyarakat. Untuk mengetahui tanggapan responden sebanyak 60 orang, maka berikut ini ditunjukkan dalam tabel 3.

Tabel 3. Deskripsi Tanggapan Responden Terhadap Pengawasan

\begin{tabular}{|c|c|c|c|c|c|c|c|c|}
\hline \multirow{2}{*}{ No } & \multirow{2}{*}{ Indikator } & \multicolumn{2}{|c|}{1} & \multicolumn{2}{|c|}{2} & \multicolumn{2}{|c|}{3} & \multirow{2}{*}{ Rata2 } \\
\hline & & $\mathbf{F}$ & $\%$ & $\mathbf{F}$ & $\%$ & $\mathbf{F}$ & $\%$ & \\
\hline 1 & Dinas Kesehatan & 5 & 8,33 & 25 & 41,67 & 30 & 50,00 & 2,42 \\
\hline 2 & Dinas Perdagangan & 7 & 11,67 & 23 & 38,33 & 30 & 50,00 & 2,38 \\
\hline 3 & Badan POM & 3 & 5,00 & 24 & 40,00 & 33 & 55,00 & 2,50 \\
\hline 4 & YLKI Prov. SulSel & 10 & 16,67 & 24 & 40,00 & 26 & 43,33 & 2,26 \\
\hline \multirow[t]{2}{*}{5} & Pelaku Usaha & 8 & 13,33 & 24 & 40,00 & 28 & 46,67 & 2,33 \\
\hline & \multicolumn{5}{|c|}{ MEAN } & & & 2,38 \\
\hline
\end{tabular}

Sumber: Hasil Olahan Data, 2019

Tabel 3 di atas, menunjukkan bahwa efektivitas pengawasan yang diukur dengan menggunakan 5 indikator pengawasan yaitu oleh Dinas Kesehatan, Dinas Perdagangan, BPOM, YLKI Sulawesi Selatan, dan Pelaku Usaha itu sendiri memiliki nilai angka rata-rata 2,38 dengan kategori cukup baik. Artinya semakin meningkat kegiatan pengawasan yang dilakukan oleh pihak yang berkepentingan di atas, semakin kondusif pasar produk makanan kemasan di Kota Makassar. Hasil penelitian ini dapat mendorong gairah konsumen untuk berbelanja di pasar karena adanya jaminan kepercayaan dan keyakinan yang diberikan oleh pihak pemerintah, lembaga konsumen dan pelaku usaha itu sendiri. Meskipun demikian, deskripsi penelitian ini juga masih memperlihatkan adanya kategori dengan nilai angka 1, artinya masih ada sebagian kecil produk yang beredar di pasaran yang lupuk dari pengawasan, meskipun itu jumlahnya relatif kecil. Hal ini tidak boleh dipandang sebagai sesuatu yang tidak pentig karena nilainya kecil, akan tetapi kalau tidak mendapatkan perhatian akan mempengaruhi kepercayaan masyarakat.

\section{d. Deskripsi Perlindungan Hukum Konsumen}

Perlindungan hukum konsumen adalah perangkat hukum yang diciptakan untuk melindungi dan terpenuhinya hak konsumen, sebagaimana yang diatur dalam UU Perlindungan Konsumen Nomor 8 Tahun 1999 adalah meningkatkan kesadaran, kemampuan dan kemandirian konsumen untuk melindungi diri, mengangkat harkat konsumen dengan cara menghindarkannya dari ekses negatif pemakaian produk barang sebagaimana penelitian ini adalah produk 
barang yaitu lebih khusus lagi adalah makanan obat dan makanan kemasan. Untuk mengetahui tanggapan responden terhadap perlindungan hukum konsumen produk tersebut yang diukur melalui lima indikator masing-massing; pemahaman masyarakat terhadap isi UU No. 8 tahun 1999, mengetahui konsistensi peneraan hukum perlindungan konsumen; adanya penyelesaian secara hukum atas sengketa secara benar, implementasi peran BPSK, dan implementasi peran yang dilakukan oleh YLKI. Hal ini dapat dilihat pada tabel 4 berikut ini:

Tabel 4. Deskripsi Tanggapan Responden Terhadap Perlindungan Hukum Konsumen

\begin{tabular}{|c|c|c|c|c|c|c|c|c|}
\hline \multirow{2}{*}{$\begin{array}{l}\mathbf{N} \\
\mathbf{0}\end{array}$} & \multirow{2}{*}{ Indikator } & \multicolumn{2}{|r|}{1} & \multicolumn{2}{|r|}{2} & \multicolumn{2}{|c|}{3} & \multirow{2}{*}{$\begin{array}{c}\text { Rata } \\
2\end{array}$} \\
\hline & & $\mathbf{F}$ & $\%$ & $\mathbf{F}$ & $\%$ & $\mathbf{F}$ & $\%$ & \\
\hline 1 & Penerapan UU No.8, 1999 & 5 & 8,33 & 25 & 41,67 & 30 & 50,00 & 2,42 \\
\hline 2 & Konsistensi Penerapa Hukum & 6 & 10,00 & 27 & 45,00 & 27 & 4500 & 2,35 \\
\hline 3 & Penyelesaian Sengketa & 6 & 10,00 & 28 & 46,67 & 26 & 43,33 & 2,33 \\
\hline 4 & Implementasi Peran BPSK & 5 & 8,33 & 26 & 43,33 & 29 & 48,33 & 2,40 \\
\hline \multirow[t]{2}{*}{5} & Implementasi Peran YLKI & 7 & 11,67 & 26 & 43,33 & 27 & 45,00 & 2,33 \\
\hline & \multicolumn{7}{|c|}{ Mean } & 2,37 \\
\hline
\end{tabular}

Sumber: Hasil Olahan Data, 2019

Tabel 4 di atas, menunjukkan bahwa tanggapan konsumen terhadap perlindungan hukum yang diterima oleh konsumen diukur dengan menggunakan 5 indikator dengan nilai angka rata-rata 2,37 dengan kategori cukup baik. Artinya semakin baik penerapan UU No. 8 Tahun 1999, keberpihakan penerapan hukum, penyelesaian sengketa, efektif peran BPSK, dan peran YLKI Sulawesi Selatan, semakin dapat menjamin perlindungan hak-hak konsumen. Kelima indikator tersebut ada dua yang kecenderungannya lebih dominan yaitu penerapan UU No. 8 Tahun 1999 dan implementasi peran BPSK (Badan Penyelesaian Sengketa Konsumen) yaitu dengan nilai rata-rata 2,42 dan 2,40 . Jika dilihat dari tanggapan kategorinya, ternyata masih terdapat tanggapan yang memiliki kategori nilai angka 1, artinya masih ada impelementasi ketujuh indikator perlindungan hukum konsumen yang masih kurang bagus.

Masih rendahnya tingkat perlindungan yang dirasakan oleh konsumen dengan menggunakan kelima indikator yang membentuk variabel perlindungan konsumen, yaitu (1) Pengetahuan konsumen terhadap UU no. 8 Tahun 1999, masih rendah hal ini disebabkan karena tingkat pendidikan dan pemahaman konsumen, kurangnya sosialisasi, dan kesadaran konsumen itu sendiri. Hasil penelitian ini mendukung hasil penelitian Darmawan Febri Padmono (2014) yang menemukan bahwa lemahnya pengetahuan dan kepedulian masyarakat. Masyarakat menilai bahwa penerapan penegakan hukum bagi konsumen yang dirugikan oleh pihak pelaku usaha sering tidak efektif terutama dalam hal ganti kerugian melalui sanksi baik aspek pidana, perdata maupun administrasi. Hasil penelitian ini mendukung hasil penelitian Ali Mansyur dan Irsan Rahman (2015). (3) Dalam penyelesaian sengketa ganti kerugian juga sering lebih didominasi oleh kepentingan pelaku usaha, mendukung hasil penelitian Golden Oktavianus Sembel (2014) bahwa dalam penyelesaian sengketa diperlukan juga di luar pengadilan supaya para pihak lebih efisien dalam penyelesaian sengketa ganti kerugian. (4) Peran BPSK tidak efektif mendukung penelitian Ridho 
Pratama (2018) yang menyimpulkan adanya hambatan antara lain karena terbatasnya anggaran untuk kegiatan di BPSK baik dalam penyediaan sarana dan prasarana yang dibutuhkan dalam penyelesaian sengketa maupun untuk kegiatan penyuluhan di masyarakat dan pelaku usaha untuk mencegah terjadinya pelanggaran terhadap UU konsumen dan luasnya wilayah kerja BPSK juga sumber daya manusia yang masih terbatas. (5) Peran YLK juga belum efektif dalam menyuarakan kepentingan konsumen Juga mendukung hasil penelitian Josef Purwadi dan Bambang Hermaya (2015) dan juga mendukung hasil penelitian Agung Nugroho (2014).

\section{KESIMPULAN}

Tingkat kesadaran hukum pelaku usaha produk makanan kemasan yang beredar di Kota Makassar memiliki kategori cukup tinggi dengan nilai rata-rata 2,48 ketujuh indikator yang membentuk variabel kesadaran hukum pelaku, meskipun demikian masih ada pelaku usaha yang memiliki tingkat kesadaran masih rendah. Tingkat kesadaran hukum konsumen dalam memilih dan menggunakan produk makanan kemasan memiliki kategori cukup tinggi dengan nilai rata-rata 2,46 , meskipun demikian, masih terdapat konsumen memiliki kesadaran hukum yang masih rendah. Pengawasan yang dilakukan oleh pemerintah, lembaga konsumen, pelaku usaha dan masyarakat memiliki kategori nilai rata-rata 2,38 sehingga dapat juga dikategorikan cukup efektif, meskipun masih terdapat pengawasan yang belum efektif. Sedang perlindungan hukum konsumen yang diterapkan selama ini bagi konsumen yang dirugikan karena mengkonsumsi produk makanan kemasan yang beredar di Kota Makassar termasuk kategori cukup baik, dengan nilai angka rata-rata 2,37, meskipun masih ada konsumen merasa kepentingannya belum mendapatkan perlindungan hukum secara maksimal.

\section{SARAN}

Diperlukan adanya peningkatan kesadaran hukum pelaku usaha dengan upaya meningkatkan pengetahuan dan pemahaman dalam mengimplementasikan tanggung jawabnya terutama dalam melakukan ganti kerugian apabila konsumen dirugikan karena mengkomsumsi produk manajan kemasan. Disisi lain juga diperlukan peningkatan kesadaran hukum konsumen terutama dalam memilih dan menggunakan produk makanan kemasan dengan menggunakan pengetahuan, pemahaman, sikap dan perilaku sesuai kebutuhan dan keinginan konsumen itu sendiri. Di perlukan peningkatan efektivitas pengawasan produk kemasan yang beredar di Kota Makassar dengan menambah frekuensi pengawasan di lapangan dengan bersinergi pemerintah, lembaga konsumen, pelaku usaha dan masyarakat. Dengan adanya peningkatan kesadaran baik oleh pelaku usaha, konsumen, dan pengawas akan tercipta adanya perlindungan hukum dalam masyarakat terutama bagi konsumen produk makanan kemasan di Kota Makassar.

\section{DAFTAR PUSTAKA}

\section{Buku}

Abu Achmadi dan Cholid Narkubo. 2005.. Metode Penelitian. Penerbit. Bumi Aksara, Jakarta. 
-------, 1996, Menguak Tabir Hukum ( Suatu Kajian Filosofis dan Sosiologis, Cetakan Kesatu, Chandra Pratama , Jakarta

Ahmadi Miru \& Sutarman Yodo, hukum Perlindungan Konsumen, PT Raja Grafindo Persada, Cetakan 6, Jakarta , 2010.

Ahmadi Miru dan Sutarman Yodo, 2004, Hukum Perlindungan konsumen, Cetakan Kesatu, Raja Grafindo, Jakarta.

Amanda Putri Sukamto, 2013. Hubungan Tentang Kesadaran Hukum Pelaku Usaha Produk Makanan Industri Rumah Tangga Dalam Memenuhi Hak Konsumen di Kota Bogor: Studi Deskriptif Tentang Keatuhan Hukum Terhadap Undang-Undang No. 8 Tahun 1999. Repository, Indonesia University of Education.

Annisa Shaliya Honesty, 2012. Upaya Indonesia Dalam Menangani Pemalsuan Obat Melalui Member State Mechanism.

Bambang Sunggono.. 2003. Metode Penelitian Hukum. Penerbit PT. Raja Grafindo Persada, Jakarta.

Basu Swasta dan Irawan (2003). Pengaruh Atribut Produk terhadap Kepuasan Pembelian Heandphone Samsung Galaxi Series. Vol. 3. No.5.

Chalid Narbuko dan Abu Achmadi. 2005. Metode Penelitiaan. Penerbit Bumi Aksara, Jakarta.

Chandra. (2006). Pengantar Kesehatan Lingkungan. Cetakan Pertama. Enerbit Buku Kedokteran, Jakarta.

Daemawan Febri Padmono (2014). Perlindungan Hukum Terhadap Konsumen Atas Penjaminan Mutu Makanan yang Beredar di Pasaran Oleh BPOM Daerah Istimewa Yogyakarta di Tinjau dari UU No. 8 Tahun 1999 Tentang Perlindungan Konsumen. Fakultas Hukum Islam Negeri Sunan Kalijaga. Yogyakarta.digilib.uin-suka.ac.id.

Fandy Tjiptono. 2008. Strategi Pemasaran. Edisi ke 3, Andi. Yogyakarta.

Freddy Rangkuti. 2005. AnalisisSWOT: Teknik Membedah Kasus Bisnis. Gramedia. Jakarta.

Gunawan Widjaja, dan Ahmad Yani, 2001, Hukum Tentang Perlindungan Cetakan Kedua, Gramedia pustaka Utama, Jakarta.

Hamsyar. 2017. Perlindungan Hukum Konsumen Terhadap Peredaran Makanan Kadaluarsa di Kota Makassar. Repository.unhas.ac.id. Fakultas Hukum Universitas Hasanuddin.

Happy Susanto, 2008, Hak - Hak Konsumen Jika dirugikan, visimedia, Jakarta

Imam Taufiq. 2017. Analisis Yuridis Perlindungan Konsumen Terhadap Peredaran Makanan Kadaluwarsa di Wilayah Kabupaten Sukoharjo. Fakultas Hukum Universitas Muhammadiyah Sukoharjo. Emprint.ums.ac.id. Iqlimatul Annisa. 2018. Perlindungan Hukum Konsumen Terhadap Peredaran Produk Kosmetika Ilegal Yang Mengandung Zat Aditif. Peneltian, Repository. Fakultas Syariah dan Hukum Universitas Islam Negeri Syarif Hidayatullah, Jakarta.

Jonaedi Efendi dan Johnny Iibrahim. 2018. Metode Penelittian Hukum, Normatif dan Empiris. Penerbit Pranadamedia Group, Jakarta.

Puspita. (2016). Kamus Besar Baahasa Indonesia 2008. Balai Pustaka FKIPunpas. Jakarta. 
Klimchuk, Marianne \& Sandra A. Krasovec. 2006. Desain Kemasan. Penerbit Erlangga, Jakarta.

Kotle dan Keller. 2009. Manajemen Pemasaran. Jilid I. Edisi ke 13. Penerbit Erlangga. Jakarta.

Kotler, P; Adam, S; Brown, L; dan Amstrong. (2003). Principles of Marketing. Edisi ke 2.

Kotler P., dan Gary Amstrong (2001). Prinsip-Prinsip Pemasaran, Edisi ke1 12, Jilid 1. Erlangga, Jakarta.

Masri Singarimbun dan Soffyan Efendi. 2008. Metode Penelitian Survei. Cetakan XIX. LLP3ES, akarta..

Meliza Edtriani. 2012. Pelaksanaan Pengawasan Balai Besar Pengawasan Obat dan Makanan (BBPOM) Terhadap Peredaran Makanan dan Minuman Tanpa Izin Edar (TIE) di Kota Pekanbaru. Kampus Bina Widya . Simpang Baru. https://media.neliti.com.

Menteri Kesehatan, 1988. Pentingnya Penerapan Teknologi Informasi di Industri Farmasi. Keputusan Menteri Kesehatan Republik Indonesia No.43/Menkes/SK/II / 1988 tentang cara Pembuatan Obat yang Baik. Jurnal unpad ac.id.article. 2017.

Mukti Fajjar ND dan Yulianto Achmad. 2010. Dualisme Penelitian Hukum Normatif dan Empiris. Penerbit Pustaka Pelajar, Yogyakarta.

Manajemen Pengelolaan Obat dan Makanan, Nuha Litera Offset, Cetakan 1, 2009, Jogyakarta

Gunawan Widjaja, Hukum Tentang Perlindungan konsumen, PT. Gramedia Pustaka Utama, cetakan 4, 2008, Jakarta

Janus Sidabalok, Hukum Perlindungan Konsumen, PT. Citra Aditya Bhakti, 2006, Bandung

Happy Susanto, Hak Hak Konsumen Jika Dirugikan, Transmedia Pustaka, 2008, Jakarta

Peraturan Menteri Kesehatan RI. 1976 tentang Produksi dan Peredaran Makanan. Nomor 329 tahun 1976.

Ridho Pratama. 2018. Peran Badan Penyelenggara Sengketa Konsumen (BPSK) Dalam Menegakkan Hak-Hak Konsumen (Studi pada BPSK Kabupaten Lampung Tengah. Digilib.unila.ac.id. Fakultas Hukum Uniiversitas Lampung Bandar Lampung

Saefullah,2000, Tanggung Jawab Produsen Terhadap Akibat Hukum Yang Ditimbulkan Dari Pada Era Pasar Bebas, dalam husni Syawali, Jakarta.

Sholehudin Abdul Aziz. 2016. Makanan Indonesia Darurat Formalin, Borak, dan Pewarna Tekstil. Artikel. Kompasiana.

Siagian, SP. 2001. Manajemen Sumber Daya Manusia. Penerbit. PT. Bumi Aksara. Jakarta.

Siahaan, H.T. 2005. Hukum Perlindungan Konsumen. Panta Rei, Jakarta.

Sri Lestari Poernomo, 2018. Analisis Perlindungan Hukum Konsumen Produk Pangan Di Sulawesi Selatan. Hasil Penelitian dalam Buku Referensi

Soejono Soekanto \& Sri Mamudji. 2001. Penelitian Hukum Normatif (Suatu Tinjauan Singkat). Penerbit Rajaawali Pers, Jakarta. 
Sugiyono. 2008. Metode Penelitian Kuantitatiff, Kualitatif, dan R\&D. Penerbit Alfabeta. Bandung.

Sujamto. 1989. Aspek-Aspek Pengawasan di Indonesia. Sinar Grafika, Jakarta.

Syamsuddin Pasamai, Metodologi Dan Penulisan Karya Ilmiah Hukum, PT.UMI Toha, 2010.

Yusup Sofie, Kapita Selecta Hukum Perlindungan Konsumen di Indonesia, PT Citra Aditya Bhakti, 2008, Bandung

Yemima Br. Sitepu, Perlindungan Konsumen dan Instrumen Instrumen Hukumnya, PT Citra Aditya Bhakti, 2008, Bandung

Zainuddin Ali, Metode Penelitihan Hukum, Sinar Grafika Offset, 2009, Jakarta

\section{Jurnal}

Afriana Ratu M.P. 2014. Perlindungan Hukum Bagi Konsumen Produk Makanan Kemasan Tanpa Label Halal di Kota Banda Aceh. Electronic Theses and Dissertaons (ETD). Vol. VI. No. 58.

Agung Nugroho. 2014. Peranan Yayasan Lembaga Konsumen Indonesia Dalam Membantu Masyarakat yang Dirugikan Akibat Iklan yang Menyesatkan. Lex Jurnalica (Journal of Law). Beranda> Vol. 11. No. 2.

Ali Mansyur dan Irsan Rahman. 2015. Penegakan Hukum Perlindungan Konsumen Sebagai Upaya Peningkatan Mutu Produksi Nasional. Jurnal Pembaharuan Hukum. jurnal.unisula.ac.id.articlle.PDF.Vol. 11. No.1 JanuariApril 2015.

Desy Ary Setyawati, Dahlan, dan M.Nur Rasyid, 2017. Perlindungan Bagi Hak Konsumen dan Tanggung Jawab Pelaku Usaha Dalam Perjanjian Transaksi Elektronik. Syiah Kuala Law Journal: Vol. 1. No. 3 Desember 2017.

Erleni. 2016. Menyisir Perlindungan Hukum Bagi Pihak yang Melakukan Transaksi Jual-Beli Melalui Internet dan Upaya Hukum Bagi Konsumen Terhadap Transaksi Jual-Beli Melalui Internet. Jurnal Disiplin. Volume 22. Nomor 9 Juli 2016.

Golden Octavianus Sembel. 2014. Penyelesaian Sengketa Konsumen Pelaku Usaha Dalam Perspektif (Suatu Kajian UU No. 8 Tahun 1999 Tentang Perlindungan Konsumen) ejjournal.unsrat.ac.id.vol.3. no.1.

Harianto D. 2016. Asas Kebebasan Berkkontrak: Problematika, Penerapannya Dalam Kontrak Baku Antara Konsumen Dengan Pelaku Usaha. Jurnal Hukum Samudra Keadilan, Volume 11, Nomor 2, Juli - Desember 2016.

Hendrawati. 2011. Penerapan Asas Kebebasan Berkontrak Dalam Pembuatan Perjanjian Baku (Studi Normatif pada Perjanjian Pembiayaan Konsumen), Jurnal Masalah-Masalah Hukum, Volume 40, Nomor 4, Oktober 2011.

Ita Oktaliani, 2016. Perlindungan Hukum Terhadap Konsumen Pangan Olahan Impor yang Tidak Mencantumkan Nomor Izin Edar Kode Makanan Luar Negerii (ML) pada Label Kemasan. E-Jurnal Gloria Yuris. Volume 4, No. 3.

Josef Purwadi dan Bambang Hermaya. 2015. Peran Badan Penyelemggara Sengketa Konsumen (BPSK) Dalam Penyelesaian Sengketa Konsumen. ejurnal.unisri.ac.id. Eksplorasi. Volume XVIII. No.1 Agustus 2015.

Ninik Azizah, 2015. Keharusan Pelaku Usaha Memberikan Informasi Yang Benar Ditinjau dari Hukum Islam dan Undang-Undang Perlindungan Konsumen. Jurnal Irtifaq. Vol. 2, No. 1, Maret 2015. P.47-73. 
Nuhzul Marnizar S. 2016. Penanggulangan Tindak Pidana Terhadap Makanan Kemasan yang Tidak mencantumkan Tanggal Kadaluwarsa (Suatu Penelitian di Wilayah Kota Banda Aceh). Electronic Theses and Dissertations (ETD). Fakultas Hukum Unsyiah. Vol. V. No. 59.

Shanti Yoseva, Eko Raharjo, Rini Fathonah. 2018. Analisis Kriminologis terhadap Produsen Makanan yang Mengandung Bahan Berbahaya (Jurnal Fakultas Hukum UNILA. Bandar Lampung.

Sri Lestari Poernomo, 2018. Standar Kontrak Dalam Perspektif Hukum Perlindungan Konsumen. Jurnal Nasional Terakreditasi. DEJURE, jakarta.

Vicky F. Taroreh. 2014. Kajian Hukum Perlindungan Konsumen Terhadap Prooduk Pangan Kadaluarsa. Jurnal Hukum. Vol. 11. No. 2. Januari - Maret 2014.

Yemima Br. Sitepu. 2016. Pertanggungjawabban Pelaku Usaha Kepada Konsumen Terhadap Promosi Yang Tidak Benar Ditinjau Dari UndangUndang Nomor 8 Tahun 1999 Tentang Perlindungan Konsumen (Studi Kasus di Toko Alfamar Kecamatan Sail). JOM Fakultas Hukum, Volume III, Nomor 2, Oktober 2016.

\section{Undang Undang}

Undang Undang Kesehatan dan Undang Undang Praktek kedokteran, CV. Karya Gemilang, 2010, Jakarta

Undang Undang Kesehatan dan Undang Undang Tentang Rumah Sakit, Citra Umbara, Bandung.

Undang Undang No. 7 Tahun 1996 tentang Pangan (Lembaran Negara RI Tahun 1997), Jakarta.

Undang Undang Republik Indonesia Nomor 18 Tahun 2012 Tentang Pangan

(Lembaga Negara RI Tahun 2012). 